\title{
Old Testament Studies: The story Of a department
}

Author:

Jurie le Roux ${ }^{1}$

\section{Affiliation:}

${ }^{1}$ Department of Old

Testament, University of

Pretoria, South Africa

Correspondence to: Jurie le Roux

e-mail:

jleroux1@mweb.co.za

\section{Postal address:}

Department of Old

Testament, University of

Pretoria, Pretoria, 0001,

South Africa

\section{Keywords:}

Pentateuch; psalms; structural analysis; historical understanding; myth

\section{Dates:}

Received: 21 Aug. 2009

Accepted: 31 Aug. 2009

Published: 17 Dec. 2009

How to cite this article:

Le Roux, J., 2009, 'Old

Testament Studies: The

story of a department',

Verbum et Ecclesia 30(3), Art.

\#182, 9 pages. DOI: $10.4102 /$

ve.v30i3.182

This article is available at:

http://www.ve.org.za
(C) 2009. The Authors. Licensee: OpenJournals

Publishing. This work is licensed under the

Creative Commons

Attribution License.

\section{ABSTRACT}

The Department of Old Testament at the Faculty of Theology, University of Pretoria, has been in existence since 1938 and this article is an attempt to highlight some aspects of its history. The article consists of two main sections. The first discusses the place of the Department in the world, in Africa and at the University. It is stated that the Department always moved with the times and re-invented itself in new contexts. It found a stronghold in the university context, addressed the problems of our times intellectually and consistently maintained international contacts. In the second section, the members of the Department are discussed individually. It will become clear that there is a strange mixture of synchrony and diachrony, of reading the text in its final form and of taking the historical context and growth seriously. Both approaches exist alongside each other and complement each other. It is concluded that the Department's future lies in its scholarly past - in the intellectual traditions in which it is embedded, and in its ability to adapt to new contexts without losing its total devotion to critical scholarship, the students and the church.

Like human beings, a university department can also have a biography. It has a life entrenched in real experiences and is subjected to the same socio-political realities as people. This article briefly tells the life story of one such department, that of the Department of Old Testament at the University of Pretoria. It describes the Department's academic endeavours, and of the scholars who devoted their lives to the pursuit of Old Testament scholarship and the teaching of theological students from their first year to doctorate level. Over the years the Department had to adjust and re-adjust, but in the end it survived all kinds of pressures and established its place both here and abroad. One of the reasons for its endurance and survival has been the commitment of the members of the Department to cutting-edge research, sound scholarship and excellent teaching. This story is told here by focusing on the physical contexts in which the Department had to exist, and then on the scholars who made things happen.

\section{INTRODUCTION}

Since its humble beginnings in 1938, the Department of Old Testament at the University of Pretoria grew along with the Faculty of Theology into a very prominent centre for Old Testament scholarship in South Africa. It presents courses to undergraduate students, supervises master's and PhD students, contributes many articles each year to national and international journals, and has important scholarly agreements with other international institutions. The Department is also constantly evaluated nationally as well as internationally and is well placed within the South African university context.

Over the past 70 years, the world in which the Department of Old Testament functions has changed dramatically. Initially its sole function was to train ministers for the Dutch Reformed Church, but since then the socio-historical context has been revolutionised and universities have had to adapt to new goals and expectations (Van Huyssteen 1986:1-10). Old Testament scholarship now had to resonate within a much wider social context and had to become part of the international discourse. International standards had to be met and a wider audience had to be reached. Put differently: Although the connection to the church remained intact, the Department (like the Faculty) adapted itself not only to the great world of scholarship, but also to the needs of the community. In other words, the Department constantly had to re-invent and re-formulate its place in the world of science, the University and Africa (Coyle 2006:13-26).

This was accomplished by a number of scholars who devoted their best intellectual talents to the building of this department and the establishment of an important scholarly tradition. The history of the Department is therefore the story of Johan Kritzinger, who was the first professor in Old Testament, and of his successor, Albertus van Zyl; of Willem Prinsloo and his two students, Dirk Human and Alphonso Groenewald, and their remarkable contribution to the study of the psalms; of Jurie le Roux, who succeeded Van Zyl; and of Eckart Otto of Munich, who, over the course of time, became attached to the Department as honorary professor and also received an honorary doctorate from the University.

To appreciate their contribution we first will focus on the contexts in which they had to work: that of the world, Africa and the University. One can even compare these foci to three concentric circles: the outer one being international scholarship, the second one Africa and the innermost circle the University. In 1938, the community and the University welcomed the Faculty and the Department, but things changed over the years. Africa began to frown upon Western theology and challenged the value of Old Testament scholarship. The international world of biblical scholarship opened up and the Department had to position itself in that world. Due to socio-political changes, faculties of theology came under pressure and the scholarly nature of biblical scholarship was questioned. Over the years the Department thus had to define and redefine its place in a landscape that was constantly changing and at times even became hostile. I will first discuss the Department's place in this wider context.

\section{A PLACE IN THE WORLD OF SCHOLARSHIP}

To strike a balance between the local and the international, the demands of the ministry and the 
wider world of scholarly work was no easy task. The members of the Department nevertheless accomplished this by following different routes, primo by studying at universities in the Netherlands and Germany. In hindsight this was a very decisive step that shaped our scholarship in a profound way. Should the lecturers have decided on America or the United Kingdom, the Department would have looked totally different. Due to cultural and language affinities, the Netherlands became a natural choice and many staff members completed doctoral studies at these universities. The first professors at the Faculty obtained doctorates in the Netherlands and the first generation of students was thus shaped to a great extent by a Dutch way of doing theology ( $c f$. Du Preez 1933; Groenewald 1932; Kritzinger 1935). Secundo, this goal was accomplished by establishing contact with German Old Testament scholars from the 1970s onwards. Because the Dutch vehemently opposed South Africa's politics, they abolished the cultural agreement between the two countries and Germany became an attractive option (Human 2006:70-73; Steyn 2008:303,393; Terblanche 1998:207-212). Willem Prinsloo (1985:1-10) and Dirk Human were both awarded scholarships from the prestigious Alexander von Humboldt Institute to pursue high-level research at prominent German universities, while Alphonso Groenewald received a grant from the Deutscher Akademischer Austausch Dienst (DAAD) to study for a doctorate on the psalms (Groenewald 2003:viii-ix). In 2000, Eckart Otto of the Ludwig-Maximilians-Universität (LMU), Munich (Germany), became an honorary professor in the Department and has contributed immensely to the study of the Pentateuch in Germany as well as in South Africa (cf. Otto 2007a:19-28; 2007b:29-53). Tertio, Willem Prinsloo's efforts played an important role in helping the Department to enter a definite period of internationalisation. He regularly attended international congresses on the Old Testament, invited renowned scholars (Protestant as well as Catholic) for lectures and made the University of Pretoria an important stopover for overseas scholars. It is important to note that Prinsloo accomplished this during the politically turbulent times of the 1980s and early 1990s. It was a period of isolation and estrangement but, due to Prinsloo's endeavours, links with the greater academic world were kept alive. Quarto, the necessary balance in the Department was struck by means of two joint projects between the University of Pretoria and the LMU, Munich. The one, Pro Pent, focuses on the Pentateuch, while the other, Pro Psalms, focuses on the psalms. These two seminars assemble yearly, with international and national scholars attending and devoting a few days to intense discussion of important themes. The papers are published internationally (Le Roux 2005:1-21).

\section{OLD TESTAMENT SCHOLARSHIP AND AFRICA'S PAIN}

Africa is a harsh continent. Sweltering heat, floods, late afternoon thunderstorms, droughts and all kinds of destructive pests have plagued Africa for centuries. Each day, poverty, AIDS, corruption and bad governance devastate the lives of ordinary people. And those who still have the courage to hope, think only of trivial things like shelter for the night, a blanket, a loaf of bread, a part-time job and clean water. Where does Old Testament scholarship fit into this context of misery, poverty and pain? How can sophisticated theories about the Old Testament or refined exegetical approaches ever ease the pain of an AIDS patient or provide for the needs of the poor, the hungry and the dislocated? How can knowledge of the Old Testament's origin and growth ever console people, reform societies or stop corruption? How can an understanding of the Pentateuch's theology or the structure of a psalm give hope to Africa's depressed and despondent people who have already given up faith in the good life that was so often promised them (Coyle 2006:13-26; De Wit 2008:3-30; Le Roux 2008a:307-323; Snoek 2008:85-106)?

It cannot! Old Testament scholarship cannot provide in these basic human needs. However, there is perhaps another way of involving Africa, of making Africa an integral part of Old Testament research, but then we have to transform our theological strategy. Since Johann Jacob Rambach's work on hermeneutics (1723), a distinction has been made between subtilitas intelligendi (understanding), subtilitas explicandi (exposition) and subtilitas applicandi (application) (Körtner 2006:33-34). Accordingly, a text must first be explained and then applied. This sequence, however, must be changed. The one 'step' is never without the other and must never be separated from the other 'steps'. Interpretation calls for application and the exegete's life context determines the exegesis of a text. The exegete's own life context (or 'praxis') influences the exegetical process right from the beginning. Right from the onset the exegete 'sees' things in the text and this is determined by his/her own life context. Exposition is thus embedded in real-life contexts and is consequently practical from the start (Albertz 1992:1-104; Gadamer 1990:309-311, 375384; Klopper 2008:183-193).

Seen from this perspective, Africa is and always has been scattered all over the work of the Department of Old Testament. South Africa was and still is present in research, teaching and writing. Africa and South Africa form the life context from which all our scholarly pursuits receive meaning and direction. This, however, does not imply the abandonment of western scholarship; quite the contrary (Le Roux 2008a:307-323; 2008b:140-142). It is only through total dedication to Old Testament scholarship that sensitivity for the contexts of Israel and Africa can be understood, developed and nurtured (West 2008:37-64). It is only through sophisticated and intellectual scholarly investigation of the Pentateuch that the two important redactions of the Pentateuch during the 4th century can be detected: the one emphasising the Torah as God's greatest gift to Israel and the other highlighting the importance of land (which is a burning issue in Africa). It is only through dedicated study of the Hebrew text that Israel's understanding of myth (which is still thriving in Africa) can be understood and explained. It is this kind of Old Testament research that dominated scholarship of the past two centuries and this critical scholarship is not only an impressive intellectual development but also contains information on how the Old Testament was appropriated in different contexts and how it addressed social issues. A similar intellectual tradition does not exist anywhere in Africa and it would be unwise and destructive to destroy what western Old Testament scholarship has to offer. Thus, for the Department, context and critical scholarship have always belonged together and will always remain the way in which the Old Testament must be approached and studied and its message formulated (cf. Albertz 1992:17-43; Grondin 1994:2439, 1995:3-43; 2001a:86-124, 2001b:152-172, 2001c:11-29; Le Roux 1997:401-423; Otto 2000a:211-233, 2002:276-313; Thiselton 1980:103-113; Von Rad 1971:9-86, 1973:289-312).

\section{A PLACE AT THE UNIVERSITY}

The Department also had to establish its position at the university. This could only have been accomplished by appropriating the goals and aims of the University of Pretoria and by defining theological education as a scholarly enterprise. Since a university is a centre for free and independent research, an agent for intellectual and cultural change, a place where new knowledge is generated, intellectual creativity promoted, critical thinking enhanced and an intellectual framework is created without which no free and open society can ever function the study of the Old Testament had to be integrated into these essential characteristics of a university. Put differently: to be authentic, the Department of Old Testament had to become part of the intellectual context of a university and had to reflect this context in its approach, method and terminology ( $c f$. Degenaar 1993:45-64; Rossouw 1993:30-73; Van Niekerk 1993a:1-10 1993b:i-iv; 1993c:1-43).

One of the impulses that made this integration possible came from the Reformation (Goertz 2008:576-601; Hobbs 2008:452511; Oftestad 2008:602-616). One could even say that Old 
Testament scholarship at the University of Pretoria was and still is executed in the wake of the 16th century Reformation ( $c f$. Opitz 2008:428-451). The impact of this Reformation on biblical scholarship can never be overestimated. The Reformation resisted the notion of an external institution (like the church or tradition or a church official) determining the exegetical process or the meaning of a text. This resistance became an enormous impetus for detailed studies of the Old Testament, which only came to full fruition in the 19th and 20th centuries (Welker 2008:91-121). To a certain extent the Reformed biblical scholar became a lonely figure after the Reformation, because he/she was now deprived of a faith community dictating, prescribing and formulating the theological essence of the Bible on his/her behalf. All that remained was the sola scriptura, the text of the Old Testament, and this gave rise to the ongoing development of extremely refined approaches and methods, words and concepts to examine the Old Testament as never before in the history of theology. As it will become clear below, the Department has not only been shaped by these impulses of the Reformation, but it has always been an integral part of the scholarly tradition that developed from the 19th century onwards (Kraus 1969:6-43; Reventlow 1997:68-90, 118-140).

Over the years the Department has thus established itself firmly in the university context, appropriated an internationally accepted scholarly tradition and become sensitive to the needs of our context. And this has been accomplished by people who have developed this department over many years. Their story is told below. We start with Johan Kritzinger, the first professor, who insisted in his own conservative way that Old Testament scholarship must form the basis for all theological reflection. Then there was his successor, Albertus van Zyl, who devoted many years to the 1983 Afrikaans translation of the Bible and who wrote important works on the Old Testament (Van Zyl 1960:1-100; 1967:2-20), but whose time and context expected him to integrate critical work and faith (cf. Barth 1962:21; 1975:408416). Something new was introduced in the Department with Willem Prinsloo, and his students Dirk Human and Alphonso Groenewald developed it further. Jurie le Roux came from Unisa and emphasised the importance of an historical understanding of the Old Testament. In 2000, Eckart Otto of the LMU, Munich, became an honorary professor in the Department and opened up new ways of understanding 'synchrony' and 'diachrony', as well as the origin and growth of the Pentateuch (Otto 1995:163-191; 1996:332-341; 1997:321-339; 1998:1-84; 1999a:1-10; 1999b:693696).

\section{JOHAN KRITZINGER: SCHOLARSHIP ESSENTIAL FOR THE MINISTRY}

From his first lecture on the Old Testament in 1938, Johan Kritzinger stressed the importance of scholarship-Old Testament scholarship. The way to the ministry had no shortcut, but passed through Old Testament scholarship and the appropriation of scientific findings. This attitude was probably developed and strengthened during his stay in the Netherlands, where he studied for his doctorate. As a young student he attended the Kweekskool (Theological Seminary) of Stellenbosch University, where he was a student of Johannes du Plessis. Later he studied at the Free University of Amsterdam, where he obtained a doctorate in 1935 on the book of Joel (Kritzinger 1935:1-10).

Kritzinger's connection with Du Plessis was not looked upon favourably, because Johannes du Plessis caused a stir in the Afrikaans community in the late 1920s and 1930s. He propagated a very mild form of historical criticism and distinguished between the Elohist, the author of the first creation story, the Jehovist, the author of the second creation narrative, the Deuteronomist, who was responsible for Deuteronomy, and the Junior Elohist, who became united with the Jehovist. Du Plessis's source criticism was not complicated and he only used it to convince the church of the importance of historical criticism. He was of the opinion that the church could no longer ignore these insights and challenges. Du Plessis never developed his Pentateuch theory further, but nevertheless agitated the Afrikaans community and the church. In the end he was dismissed from his post as professor in theology at the theological seminary of Stellenbosch University. Du Plessis appealed to the higher court, which returned a verdict in his favour (Du Plessis 1926:80-87,100-106; 1927:23-26; Deist 1986:36-65).

Kritzinger was a student of Du Plessis and, in his thesis, made two very small references to Du Plessis that caused him much trouble. In the one reference Du Plessis is thanked for the interest he took in him as a young student (Kritzinger 1935:Voorwoord). In the second reference, Kritzinger supports Du Plessis in his criticism of the translators of the Afrikaans Bible, who used the 'textus receptus' (Kritzinger 1935:Stellings). These two innocent remarks were enough to cast a shadow of doubt over him and the Department. Some saw him as a Du Plessis supporter and questioned his conservatism.

Kritzinger was no follower of Du Plessis. Quite the contrary. He was steeped in the reformed tradition and approached the Bible from a conservative point of view. Part of this conservative view was early dating. Put differently: A conservative take on the Old Testament implied an early dating of the prophets, a dating before the exile as well as the insistence on the historicity of Joel as prophet and as author. Although acquainted with radical works (radikaal-kritiese werke), he usually sided with the behoudende Skrifverklaarders. He constantly avoided historical criticism and took his reformed understanding of the Old Testament seriously. According to his students he indeed referred to and discussed critical scholarship, but in the end would always say: 'We conclude with Aalders' - Aalders being a very reformed and conservative Dutch scholar whose work had a very important influence in the early stages of the development of Old Testament scholarship in South Africa (Aalders 1952:5$23,199-288)$. Kritzinger's health, however, deteriorated at a very early age and this prevented him from undertaking extensive research and publications, but he nevertheless had a great influence on the first generation of students (Kritzinger 1939:120; 1963:77-85; 1965:2-5).

\section{ALBERTUS VAN ZYL: FAITH AND SCHOLARSHIP ARE INSEPARABLE}

Van Zyl succeeded Kritzinger in 1966. By that stage the ghost of Du Plessis had faded, but an anti-historical-critical attitude towards the Old Testament and the Pentateuch prevailed (Deist 1986:36-65). Van Zyl knew quite well that the insights and the results of critical Old Testament scholarship could never be denied and that they had to be used in a constructive way to serve the study of the Old Testament as well as the church's needs. However, to work critically was not enough. Something else was necessary: a confession of faith. By means of such a confession Van Zyl was able to unite two seemingly irreconcilable poles, namely critical scholarship and Biblical authority. This was a very typical attitude of South African scholars (even more so after the Du Plessis case): to be able to take historical criticism seriously, one had to make an audible confession of faith. The Old Testament can only be investigated critically as long as its authority is not endangered. Faith and critical study had to be united and the latter had to be kept in check by faith, so to speak.

To Van Zyl, the Old Testament was the revelation of God and therefore the book of the church (Van Zyl 1975:47-52). He continually emphasised that science should bear this in mind (Van Zyl 1970:186), and his work on the Pentateuch serves as a good example. He pays ample attention to the introductory questions, but does not leave it at that. He makes a thorough analysis of the Pentateuch to explain its historical origin and then utilises the results to reach its theological core. Critical science is thus at the service of preaching (cf. Van Zyl 1987:1225). 
Van Zyl contributed greatly to the demythologising of the word 'critical'. In the northern part of the country in particular a historical-critical study of the Old Testament was no longer a forbidden way of doing scientific research, but rather a necessity. A critical approach held that the Old Testament could be analysed thoroughly, scientifically and critically and that all problems could be brought into the open, without fear of undermining Scriptural authority. Van Zyl's work also bears testimony to a fearless grappling with critical Old Testament scholarship, and by doing this he opened up possibilities for future generations to go further (Van Zyl 1972a:65-76; 1972b:149 159; 1973:114-125; 1983:2-111).

\section{WILLEM PRINSLOO: THE FINAL TEXT IS THE POINT OF DEPARTURE}

With Willem Prinsloo, a new stage in the intellectual history of the Department was entered into. He was young when he joined the Faculty in 1974 and devoted himself to the study of the Old Testament (and especially the psalms) with great enthusiasm and energy. As said above, he aimed at making the Department more international and therefore facilitated many long and short visits of international scholars to the Faculty. He also fostered these relations by visiting and meeting overseas scholars and attending international congresses.

In the early 1970s, Prinsloo became part of an exegetical movement in biblical scholarship, which forever changed the face of South African theology, and of biblical studies in particular (Vorster 1971:139-148; Le Roux 1993:27-28; 2007:118). It was a kind of paradigm shift, which turned existing views on the text and exegesis upside down and had a long and very persistent influence on Old Testament scholarship. According to this movement, a clear distinction should be made between synchronical and diachronical linguistics (and the notion that synchrony always precedes diachrony); the final text became the starting point of all exegetical work; a specific method (structural analysis and the techniques of modern linguistics) became 'normal science' and a sign of sound exegesis; and a particular vocabulary (diachrony, synchrony, structural analysis) not only supported the method, but also defined the hermeneutics of the new approach (the text must be understood from itself, historical information must be disregarded) (Le Roux 1993:28-33; 1994:132). In short: Language became decisive and it was thought that language utterances were self-regulatory (they are not organised according to fixed external principles), self-sufficient (they do not need external information), self-contained (the meaning lies within the utterance) and self-reliant (its meaning is determined by itself) ( $c f$. Loader 1978:1-40).

Willem Prinsloo was not only part of this movement, but also played a crucial role in appropriating and popularising it for our context (Prinsloo 1979:201-210; 1980:331; 1981:432-433; 1983:255-256; 1984:58-72,115-135, 136-153; 1987:1-20; 1988:196209; 1991:1-23; 1992:66-81). It was thus due to him that this method became the dominant model for Old Testament exegesis at our Faculty and Department, especially for students of the Dutch Reformed Church (Le Roux 1993:277-293). In the initial phases of this new way of thinking, Prinsloo took great pains to become acquainted with all aspects of the method and, in due course, he became an authority on structural analysis. He clearly illustrated the new method's possibilities: He applied the method with such thoroughness that others were convinced of its value; he stressed that it was a great improvement on the historicalcritical method, with its one-sided focus on the growth of the text; he was convinced of this method's ability to illuminate the message of the Old Testament; and he contributed to the view that good Old Testament scholarship must be accomplished along the lines of structural analysis. Prinsloo's influence was so overwhelming that he shaped the minds of generations of theological students studying the Old Testament: he trained them to explain the Old Testament to their congregations by means of a structural analysis; preaching was to be based on the results of a structural analysis of the Old Testament; and this method was also the only route to advanced study of the Old Testament for his postgraduate and doctoral students. The influence of this approach to the Old Testament is still clearly visible at church meetings (Le Roux 1993:32).

Dirk Human and Alphonso Groenewald were two of Prinsloo's students. They followed his cue and continued his work on the psalms, albeit in a different manner and with different questions in mind. To a certain extent the 'master paradigm' (final text, detail exegesis, structural analysis) remained, but over the course of time more and more problems with the existing 'immanent approach' were discovered and formulated. Critical questions pertaining to methodological pluralism, history, life-context, Ancient Near Eastern influences etc. were posed and had to be addressed. Human and Groenewald dealt with these problems in their own way, however, and their typical approaches to the text are depicted below. Human's treatment of myths in the psalms illustrates that this subject can only be treated adequately by means of thorough exegesis. According to Groenewald, a historical or diachronical approach on the one hand, and a text-immanent or synchronical method on the other, need not exclude one another.

\section{DIRK HUMAN: NO SUBSTITUTE FOR THOROUGH EXEGESIS}

Human continued with the exegetical tradition that he learned from Prinsloo, but broadened the exegetical perspective by not focusing on the structure alone, but also taking context-related issues into account. At the heart of his approach lay the notion of detailed exegesis. Nothing circumvented this and there were no exegetical shortcuts. His exposition of Psalm 93 in the context of ancient myths serves as a case in point. Studying ancient myths and their relation to the psalms opened up the amazing world in which Israel had to express and articulate their faith by using, reinterpreting and re-formulating ancient mythological ideas and concepts about the struggle between the gods and the powers of chaos. To detect and 'see' this in the text requires a meticulous analysis of the psalm (cf. Human 2004:73-88; 2005:74-96; Prinsloo 2000:141-154).

All too often, talk about myth is so vague and general that the text is never explained and the contents never illuminated. Human's detailed exegesis undermines these vague depictions of the psalms and myth by emphasising a thorough, scholarly discussion of texts. By doing so he is complying with one of the important tenets of science, which is to be specific. Scientific knowledge grows by making concrete assertions (like 'it is going to rain in five minutes'), and not by making vague, general statements (like 'it is going to rain at some stage'). Knowledge about a psalm and its mythical context grows by means of an investigation of the smallest detail in the text, and the explanation of this information in terms of specific literary and historical contexts (cf. Popper 1968:281).

It must be stressed, however, that 'myth' is a thorny issue. Time and again it has been associated with fiction, fairy tales and untruth. But people in ancient times had a different view. According to them, myth was important and could never be overemphasised. It was a way of mediating the truth, of expressing the inexpressible, saying the unsayable, conveying that which was unconceivable, mediating divine realities to ordinary people, sustaining them in their daily struggles, and of enabling them to find meaning in their everyday life. In polytheistic religions, myths dealt with gods, their struggles and interventions in the world of humans. The acts of the gods were often re-enacted in the cult and this was a way of saying things which could not be said otherwise. Myths thus played a decisive role in the Ancient Near Eastern world, and Israel did not escape their influence (Human 2007:148-150). Israel formed an integral part of that world and its culture and was acquainted with gods, demons and myths. The Old Testament still reveals traces of this 
confrontation with myths and mythological thinking. And, since a trace never exists in its fullness but only hints at what was, these marks (like structure, style, vocabulary) in Psalm 93 must be scrutinised, detected and highlighted by means of detailed exegesis (cf. Derrida 1995:372-395; 1997:102-107).

In detecting the mythological traces in the psalm, Human focused on the smallest detail and integrated all the detailed information into a larger narrative (Human 2007:152-160). He focused on the linguistic, stylistic (for example repetition, parallelism, inclusion) as well as poetic features of the text; its literary and theological qualities; the usage of nominal (vv. 2,4) and verbal clauses (vv. 1,3,5); the shift between perfect (vv. 1,3,5) and imperfect (vv. 1b,3b,5) verb conjugation; the alteration between third person descriptions (vv. 1,4) and the second person form of address (vv. 2, 3,5); and the appearance of bicola (vv. 1,2) and tricola (vv. 3-5) (Human 2007:160-166). Special attention was also paid to the literary context, the interwoveness of individual psalms with each other, and the (literary, theological) threads binding the psalms together. Psalm 93 is thus understood within its immediate literary context:

Psalm 93 links up closely with Pss 95-100 and tends to be a bridge psalm between PSS 90-92 and 94. In this regard the linguistic and semantic interwoveness between Pss 93 en 92 ... and between 93 and $94 \ldots$ is convincingly attested to. And, since Psalms 92 and 94 anticipate the destruction of enemies, Psalm 93 is linked to both by its emphasis on Yahweh's supremacy and strength over all chaos powers.

(Human 2007:154)

From Psalms 93 it is clear, however, what happened when ancient myth 'collided' with Israel's faith in Yahweh: it was stripped of its original meaning, demythologised and used in a totally different context. In this process, mythical elements were severed from their original context, lost their original purpose and were now used in a different religious context (Human 2007:147-148). Thus, although the waters create tension, anxiety and a feeling of imminent catastrophe, Yahweh remained high above and was mightier than the waters and the chaos. Yahweh was king from the beginning of times and did not become one like Baal and Marduk; he had chosen a mountain, that is Zion, which was the centre of the universe, which served as his throne and from which he ruled heaven and earth. Because all mythological motives were integrated in and moulded, redesigned and remodelled by the Yahweh faith, Psalm 93 became a king psalm proclaiming Yahweh's eternal kingship (Human 2007:168-169).

And this triumph of Yahweh happens in the text: on the page in black and white. To illustrate, we mention but one example. In verse 3 one feels the power of water: 'The raging waters have lifted up, O Yahweh, / the raging waters have lifted up their voice; / the raging waters lift up their pounding waves'. The sound of many waters emphasises danger, but Yahweh remains high above them, and he is mightier than the waters and the chaos (Human 2007:160). The noise of water alludes to Baal, the storm god, and Yam, the god of chaos; there are also vague references to the Babylonian creation epic and the celebration of Marduk's victory over Tiamat. However, unlike in the Ugaritic and Mesopotamian myths there is no sign of a struggle between Yahweh and the enemies. Yahweh is triumphant and this can be seen in the printed text; on the linguistic level where, 'by means of comparatives and a climactic stair like parallelism', his victory is jubilantly described (Human 2007:164).

Human also placed this theology in a specific time frame. It happened in the post-exilic years when the influence of Ugaritic and Canaan religion was at its strongest in the satrapy of Judah, and when the faith community experienced the strong impact of Baal-Yam and Baal-Mot. The post-exilic community reacted to these influences by using, reinterpreting and reshaping these myths to fit the Yahweh faith. Put differently: This community not only experienced the immensely destructive socio-political powers of the Babylonian exile, but also survived them. To reshape their lives and reformulate their faith, mythological ideas, terms, words and expressions were used and reinterpreted. To emphasise Yahweh's kingship during these bleak years they employed myths that they had shaped to fit their own theological purpose (Human 2007:166-168).

The insights above can only be gained by thorough exegesis, by focusing on the smallest detail in the text, by a close reading of each word and by detecting the psalm's place within the Psalter. This kind of exegesis has become an important feature or 'trademark' of the Department.

\section{ALPHONSO GROENEWALD: SYNCHRONY AND DIACHRONY ARE INTERTWINED}

Groenewald reaffirmed the basic approach (structural analysis) and vocabulary (synchrony, final text, structures, etc.) of his teacher Prinsloo, but also articulated the diachronical or historical dimensions of a text (cf. Groenewald 2004:62-72). It was especially the Old Testament's nature that compelled him to look further than the final text or the individual psalm. The Old Testament originated over a very long time, was re-interpreted in different eras from different perspectives, and was subjected to revision and rewriting. And the Old Testament's attraction and richness lies exactly in this complex origin and growth, which occurred over so many centuries. One can 'even assert that the power of the Old Testament literature actually lies in this long, involved process' (Groenewald 2007b:108).

This historical dimension had to be taken seriously in any study of the Old Testament. Groenewald compares the Old Testament to a cathedral built over many decades, or even centuries, revealing the architectural styles that prevailed in each epoch during which it was built. And whoever wants to understand the cathedral has to take its building history seriously, has to understand the different styles and how they were influenced by their times. Something similar can be said about the Old Testament: The layers of the Old Testament were put together like building blocks over many years, and these layers highlight the Old Testament's long development, as well as the particular theological thinking of a specific period in Israel's existence (Groenewald 2007b:109).

How these different historical building blocks should be identified and studied and their message be expressed are no easy tasks. Groenewald ventured an answer by taking his cue from the South African context and the endless reflection on synchrony and diachrony. South African biblical scholars have vigorously continued this intellectual debate and Groenewald used these perspectives to explain his own views and approach. $\mathrm{He}$ is, however, adamant in his rejection of a certain kind of historical or historical-critical thinking, which he considers a rude kind of positivism, a search for facts, a factual or positivistic reconstruction of the context, a romantic urge for the originals, a one-sided focus on the earliest forms of Israel's literature. Or, as Willem Prinsloo once said: 'Historical criticism must face the charge that, on the strength of its romantic supposition that the earliest source is the most authentic or the best, it has often failed to take proper account of the final text. In this attempt at reconstructing the so-called 'original' text it makes so much of the origin and growth of the final version that the latter is largely neglected' (Prinsloo 1985:2). Despite criticism of it, a diachronical study should never be rejected. It must never be an either-or situation or a choice between a synchronical or a diachronical approach to a psalm. Both should be used and the one should compliment the other (Groenewald 2005:50-62).

Groenewald therefore opts for 'a diachronically reflected synchronic reading of the text' (Groenewald 2003:9). Or, as he described it in a major study on Psalm 69, 'an independent, comprehensive text-immanent analysis involving a consideration of morphological, syntactic, stylistic and semantic aspects of the text in view of the structure of the psalm' (Groenewald 2003:4). 
This kind of text analysis led Groenewald to diachronical problems and questions within the psalm. Put differently: His thorough close reading of the text opened up problems that had to be addressed historically. This may seem rather straightforward and easy, but a combination between synchrony (in which Groenewald and South African Old Testament scholarship were steeped) and a diachronical understanding was an enormous contribution to our understanding of the psalms. Since these two approaches were always set over and against each other Groenewald really showed us a new way, a way in which both approaches could be used and combined in many different ways (cf. Le Roux 1993:270-299).

Apart from the synchrony-diachrony relationship there was also something else that Groenewald emphasised: The relationship between the whole and the part, between the individual psalm and the whole of the Psalter. One could even say that this blending of a historical and a synchronic way of doing led to a much greater appreciation of the Psalter as a whole, of the canonical order of the psalms and the internal links between the individual psalms (Groenewald 2007a:9-25). Editors have shaped the individual psalms into a canonical unity, and their intentions and principles for ordering the psalms as they have must be explored. To discover something of the editors' 'hidden' commentary, the position of the individual psalm within the Psalter as a whole must be taken seriously. Underlying this approach is the notion that the editors deliberately attributed a specific position to each psalm and that there is a possibility that their intentions can be detected and described. This, however, does not imply that the individual psalm must be neglected for the sake of the whole. Each psalm's structure, literary build up and plot must still be examined and its literary context must be determined, but its particular tone of voice must also resonate amongst the other voices in the Psalter. Obviously such an approach has consequences. A clear distinction is now being made between the creator of the original psalms and the later editors, between the origin and growth on the one side and the later editors on the other. An individual psalm is never to be studied in isolation from the other psalms. Its position within the Psalter and the various ties that link it to other psalms must always be taken into account. The psalms thus have to be read 'as literary entities and canonical wholes' (Groenewald 2007b:114).

\section{JURIE LE ROUX: TEXTS AND THEIR LIFE CONTEXTS}

Jurie le Roux joined the Faculty in 1987 and followed a historical interpretation of the Old Testament. He first studied church history, focussing on the early church, and only later turned to the Old Testament. While toiling with patristic texts he came to realise the importance of historical work for life and theology (Pannenberg 1970:36-37; Körtner 2006:11-15). Each historical document or text, such as the Hebrew Old Testament, took shape in real human life and was thus embedded in true-life experiences and therefore expresses these life experiences. This can onlybeunderstood by means of re-enactment ('Nacherleben') or re-living of Israel's past (Grondin 2002:36-51). History is thus extremely human and it deals with life, our lives. All history must start with the humbleness of our own humanity and our own humble existence. Historical investigation illuminates the many facets of our shared humanity; it is a way of relating to life and its challenges, a way of discovering life's meaning by understanding the lives of others, a way of understanding humanity's hopes and fears, and a means of providing some direction and orientation in this life (Ankersmit 1990:45-77; 1993:5-50; Heidegger 1998:496-497).

However, it is this human frailty that enables us to enter Israel's world through the text of the Old Testament, which is also a very human book. It narrates God's history with Israel as understood, experienced and re-told by Israel himself. Israel interpreted and described the mighty deeds of Yahweh (like the creation, patriarchs, exodus, desert, Sinai, conquest and later the promise to David) from his perspective. And the Israelites interpreted these deeds differently in different epochs of their history (Von Rad 1971:9-86; 1973:289-312; Le Roux 1992:291-300; 2004:123130). To be more precise, God's acts in the past were interpreted and made contemporary within a context; people actualised God's historical deeds in the light of their present situation, they contextualised their history from their perspective of faith, and continuously re-told, relived and re-enacted their past.

There thus was a movement in Israel's constant reflection and re-telling of their faith, and we must attempt to become part of that world. One way of entering that world is to continue the re-telling of Israel's story and to re-live it in our own minds (Ankersmit 2007:78-107). To be able to narrate the Bible or to make it actual and relevant for our times, we must first of all feel our way into the life experiences of Israel, relive their past experiences, re-enact that past in our mind and, especially, re-tell that story (like Israel) in our own words. Thus, the actualisation of the Old Testament for the present day depends on the exegete's competence to immerse him-/herself in the text and relive Israel's past (Collingwood 1994:441-422; Gadamer 1957:44-56; 1966:1970:184-198; 1985:350-361; 1990:112-113).

To be able to re-live and re-tell Israel's past we once again have to discover the possibilities of historical-critical investigation. During the 20th century, this way of understanding came under great pressure and its shortcomings and limitations were exposed dramatically, but in the end it remains a very efficient way of describing the Old Testament's origins and growth, as well as Israel's historical context (cf. Kraus 1969:1-100). Linking up with historical criticism and the historical insights of the past two centuries, we can at least understand some aspects of Israel's constant process of interpretation and re-interpretation, appropriation and actualisation. In the historical-critical understanding of the Old Testament thus lies the impulses that can enable us to understand something of the process of exegesis and actualisation. It remains, of course, an imaginative construction and a creative remaking of Israel's past, but one that can enable us to experience something of Israel's world (Berlejung 2009:59-192; Gadamer 1990:9-15,108-129,133-139, 276-290; Gertz 2009:193-311; Le Roux 2007:1-18).

\section{ECKART OTTO: A NEW WAY OF UNDERSTANDING THE PENTATEUCH}

Eckart Otto is a distinguished German Old Testament scholar of Ludwig Maximilian University in Munich. He is a prolific author, having written more than 400 articles, books and reviews, is renowned for his theory of the Pentateuch's origin and growth (Zenger 2008:112-118), is a specialist on Israelite and Ancient Near Eastern law texts, is editor in chief of a wellknown scholarly journal focusing on ancient law material, and is reputed for his two volumes on Max Weber's sociology of religion published in the Max Weber Gesamtausgabe. Otto is an honorary professor of the Faculty of Theology, received an honorary doctorate from the University of Pretoria in 2007, and visits the Faculty each year for lectures and discussions.

One of his many valuable contributions is his emphasis on the connection between the Pentateuch's growth and the burning theological and ethical questions with which Israel had to grapple (cf. Otto 1994:1-100; 1995:163-191; 1996:332-341; 1997:321-339; 1998:1-84; 2007c:26-37 ). To appreciate Otto's views of the Pentateuch it is first necessary to understand his starting point. Put differently: If one wants to detect these different layers and discover the intense theological-ethical debates underlying the Pentateuch, where must one begin? For many decades scholars have started with Genesis, identifying the sources or authors like the Yahwist and P (the Priestly author), but Otto resisted this. He believes that more is achieved when one starts with the book of Deuteronomy (cf. Otto 1995:163-191; 1996:332-341; 1999a:1-14). Deuteronomy is the cradle of the Pentateuch and therefore one should start there. According to Otto, recent 
Pentateuch studies suffer from 'Deuteronomiumsvergessenheit'. Pentateuch study should form part of Deuteronomy research and Deuteronomy needs to be interpreted as an integral part of the literary history of the Pentateuch. According to Otto, the Pentateuch owes its existence to the theological concepts and insights of Deuteronomy. The Pentateuch

als ganzer entsteht durch den Ruckgriff auf Konzeptionen des Deuteronomiums ... sondern vor allem auch die $d t r$ Fortschreibungen des dtn Deuteronomiums die Weichen fur die Konzeptionen von Hexateuch und Pentateuch gestellt haben.

(Otto 2000a:4)

In short, knowledge of the origins of Deuteronomy is indispensable for understanding the Pentateuch, the Archimedes point of all Pentateuch research (cf. Otto 1994:175-219; 1997: 21339; 1999b:693-696; 2000b:43-83)

Otto's contribution can hardly be overemphasised. He integrated Pentateuch theory and ethics, historical context and theology, Israel's history and the burning theological issues of the time, the Pentateuch's origin and growth, and the great problems of life with which ordinary people struggled. Pentateuch criticism thus does not stand over and against theology, the Bible or the church. By means of critical research the theological layers of the Pentateuch can be understood and the consequences for church and society be explained (Otto 2007a:19-28; 2007b: 29-53; 2007c:26-37).

\section{TWO IMPORTANT PROJECTS}

Pro Pent and Pro Psalms are two important international scholarly seminars focusing on the Pentateuch and the psalms. In August 2000, Pro Pent (Projek vir Pentateugstudies/Project for Pentateuchal Studies) was founded as a joint project between the University of Pretoria and the Ludwig Maximilian University of Munich (Germany). Pro Pent is an activity of the Department of Old Testament and aims at promoting Pentateuch research. Jurie le Roux and Eckart Otto are the leaders of this project and are responsible for organising Pro Pent, which assembles each year in Pretoria or Munich (Le Roux 2005:1-21).

For many reasons, Pentateuch research has been neglected in South Africa and Pro Pent wishes to fill this gap. Western thinking and scholarship have shaped our Old Testament research profoundly and Pro Pent is not only standing in this intellectual tradition but also wants to nurture it (Le Roux 1993:88-203). Scholarly integrity demands that our project should be linked to the ongoing debate on the Pentateuch and not fall back on precritical thinking about its growth, authorship and theology. And, as a starting point, we therefore use the views of our Münchener partner, Eckart Otto, which serve as a 'working theory'. As we mentioned earlier, the value of Otto's theory is that it aims at integrating Pentateuch theory and ethics, the historical context and the theological questions of the time (Otto 1997:321-339; 1998:1-84;1999c:1603-1606; 2005:22-49). Every redactional phase in the growth of the Pentateuch addresses a specific question or problem and this must be identified and highlighted.

To illustrate this point we refer to Deuteronomy's earliest redaction and its Neo-Assyrian context during the 7th century BCE (Otto 1999a:15-109; 1999b:693-696). During this period, Essarhaddon expected absolute obedience from Israel and threatened them with death in the case of insubordination. The Jewish intellectuals resisted and formulated their own 'theology of resistance', which can be found in Deuteronomy 13:1-18. These 'judäischen Intellektuelen' took over the Assyrian totalitarian ideas and terminology and rewrote them in such a way as to honour Yahweh alone. Whilst resisting in this way, Israel discovered his own identity and realised the uniqueness of his God (Otto 1998:1-84; 2000a:234-73; 2000b:43-83). This deed of resistance was not only the beginning of Deuteronomy and the Pentateuch (Otto 1999a:1-90), but also the beginning of the long road to our present-day concept of human rights (Otto 2002:167-194). Thus,
Pro Pent is interested in cutting-edge theories to understand the Pentateuch's redaction, how it was embedded in Israel's real-life experiences and the consequences for present-day life.

The exegetical tradition, which was developed by Prinsloo and elaborated by Human and Groenewald, and its 'application' to the psalms can never be overestimated. These scholarly endeavours gave rise to Pro Psalms, a seminar for psalm scholars who assemble each year to discuss a specific theme relating to the psalms. Pro Psalms is also a joint project between the University of Pretoria and the LMU. Typical features are the high-level scholarly debate, the in-depth analysis of the text, the thorough investigation of certain themes, the dissemination of the findings by means of books (published by T\&T Clark) and articles (in subsidised journals), the consistent application and elaboration of an exegetical tradition, which was shaped by the so-called Pretoria group of psalm exegetes, the link to the international debate on the psalms, and the enthusiasm of the group. Their contribution to the Faculty and the students can be phrased in the question: 'Have you scrutinised the text and have you explored all exegetical possibilities?'

\section{A LAST WORD}

Some aspects of the Department's life story have been told here. We have referred to its place in the world, in Africa and at the University, and the constant process of re-discovering and reinventing itself in an academic context that is changing all the time (Figal 2002:102-125). We have highlighted the views of those who worked hard and immersed themselves in scholarship, research and the writing of books and articles, thus contributing immensely to the Department's growth and development. One important aspect of their work, however, has not been mentioned yet, something without which the Department would not have excelled nor had any appeal to students, and that is the attitude and approach of the members of the Department to the Old Testament. From the earliest beginnings of the Department the Old Testament has never been approached in a detached and formal way, merely describing objectively what was going on in the Hebrew text or what happened in the history of Israel (Kearney 1986:44-50). It was interpreted as a book that is meaningful for our existence, something useful for the church and everyday life. It was explained in its existential everydayness as a book that can console, comfort and encourage. It was studied as the book of the church, which is preached, used for pastoral care, teaching and many other purposes (Kaiser 2003:393-424; Le Roux 2008a:307-323; 2008b:140-142). In short: The driving force behind the Department's endeavours was this belief that the Old Testament has meaning for our concrete historical life, and that the best way to determine this meaning runs through scholarship - critical scholarship of the Old Testament. And if anything has been achieved in this regard we want to express our gratitude in the words of the psalmist: unto us, O LORD, not unto us, but unto thy name give glory, for thy mercy, and for thy truth's sake.

\section{REFERENCES}

Aalders, G.Ch., 1952, Oud-Testamentische kanoniek, Kok, Kampen.

Albertz, R., 1992, Religionsgeschichte Israels in alttestamentlicher Zeit, vol. 1 \& 2, Vandenhoeck \& Ruprecht, Göttingen.

Ankersmit, F., 1990, De Navel van de Geschiedenis, Historische Uitgeverij, Groningen.

Ankersmit, F., 1993, De historische ervaring, Historische Uitgeverij, Groningen.

Ankersmit, F., 2007, De sublieme historische ervaring, Historische Uitgeverij, Groningen.

Barth, K., 1962, Anselm. Fides quaerens intellectum, The World Publishing Company, Cleveland.

Barth, K., 1975, Die Protestantische Theologie im 19. Jahrhundert, Siebenstern Taschenbuch Verlag, Hamburg.

Berlejung, A., 2009, 'Geschichte und Religionsgeschichte des Antiken Israel', in A. Berlejung \& K. Schmid (Hrsg), 
Grundinformation Altes Testament, pp. 59-192, Vandenhoeck \& Ruprecht, Göttingen.

Collingwood, R.G., 1994, The idea of history, Oxford University Press, Oxford.

Coyle, J.K., 2006, 'Particularities of Christianity in Roman Africa', Studia Patristica XXXIX, 13-26.

De Wit, H., 2008, 'Exegesis and contextuality: Happy marriage, divorce or living (apart) together?' in H. de Wit, \& G.O. West (eds.), African and European readers of the Bible in dialogue, pp. 3-30, Brill, Leiden.

Degenaar, J., 1993, Die konsep van die intellektueel, in A. van Niekerk \& W. Esterhuyse (eds.), Intellektueel in konteks, pp. 45-64, RGN, Pretoria.

Deist, F.E., 1986, 'Johannes du Plessis en die belydenisskrifte', Africa Journal of Evangelical Theology, 19, 36-65.

Derrida, J., 1995, Points ..., Stanford University Press, Stanford

Derrida, J., 1997, Limited Inc., Northwestern University Press, Evanston.

Du Plessis, J., 1926, 'De Inspiratie van de Schrift', Historische Zeitschrift 4, 80-87, 100-106.

Du Plessis, J., 1927, 'Feit en Theorie in 't Inspiratiebegrip', Historische Zeitschrift 5, 23-26.

Du Preez, A.B., 1933, Die dualistiese inspirasieleer, W.D. Meinema, Delft.

Figal, G., 2002, 'The doing of the thing itself: Gadamer's hermeneutic ontology of language', in R.J. Dostal (ed.), The Cambridge companion to Gadamer, pp. 102-125, Cambridge University Press, Cambridge.

Gadamer, H.-G., 1957, 'Was ist Wahrheit?', in Gesammelte Werke, vol. 2, pp. 44-56, J.C.B. Mohr, Tübingen.

Gadamer, H.-G., 1970, 'Sprache und Hermeneutik', in Gesammelte Werke, vol. 2, pp. 184-198, J.C.B. Mohr, Tübingen.

Gadamer, H.-G., 1985, 'Grenzen der Sprache', in Gesammelte Werke, vol. 8, pp. 350-361, J.C.B. Mohr, Tübingen.

Gadamer, H.-G., 1990, Wahrheit und Methode, JCB Mohr, Tübingen.

Gertz, J.C., 2009, 'Die literatur des Alten Testaments', in A. Berlejung \& K. Schmid (Hrsg), Grundinformation Altes Testament, pp. 193-311, Vandenhoeck \& Ruprecht, Göttingen.

Goertz, H.-J., 2008, 'Scriptural interpretation among radical reformers', in M. Sæbø (ed.), Hebrew Bible/Old Testament. The history of its beginnings, vol. 2, pp. 576-601, Vandenhoeck \& Ruprecht, Göttingen.

Groenewald, A., 2003, Psalm 69: Its structure, redaction and composition, Lit-Verlag, Munster.

Groenewald, A., 2004, 'Cult-critical motif in Psalm 69.32 - does it portray an anti-cultic stance?' in D.J. Human \& C.J.A. Vos (eds.), Psalms and liturgy, pp. 62-72, T\&T Clark, London.

Groenewald, A., 2005, 'Synchrony and/or diachrony: Is there a way out of the methodological labyrinth?' in E. Otto \& J.H. le Roux (eds.), A critical study of the Pentateuch: An encounter between Europe and Africa, pp. 50-62, Lit, Munster.

Groenewald, A., 2007a, 'From myth to theological language', in D.J. Human (ed.), Psalms and mythology, pp. 9-25, T\&T Clark, New York.

Groenewald, A., 2007b, 'Changing paradigms: Old Testament scholarship between synchrony and diachrony', in J.H. le Roux \& E. Otto (eds.), South African perspectives on the Pentateuch between synchrony and diachrony, pp. 108-123, T\&T Clark, New York.

Groenewald, E.P., 1932, Koinonia by Paulus, Meinema, Delft.

Grondin, J., 1994, Der Sinn für Hermeneutik, J C B Mohr, Tübingen.

Grondin, J., 1995, Sources of hermeneutics, State University of New York, Albany.

Grondin, J., 2000. Einführung zu Gadamer. Tübingen: J C B Mohr.

Grondin, J., 2001a, Der Sinn für Hermeneutik, Wissenschaftliche Buchgesellschaft, Darmstadt.

Grondin, J., 2001b, Einführung in die Philosophische Hermeneutik, Wissenschaftliche Buchgesellschaft, Darmstadt.

Grondin, J., 2001c, Von Heidegger zu Gadamer, Wissenschaftliche Buchgesellschaft, Darmstadt.
Grondin, J., 2002, 'Gadamer's basic understanding of understanding', in R.J. Dostal (ed.), The Cambridge companion to Gadamer, pp. 36-51, Cambridge University Press, Cambridge.

Körtner, H.J., 2006, Einführung in die theologische Hermeneutik, Wissenschaftliche Buchgesellschaft, Darmstadt.

Heidegger, M., 1998, Zijn en tijd, SUN, Nijmegen.

Hobbs, R.G., 2008, 'Pluriformity of early Reformation scriptura interpretation', in M. Sæbø (ed.), Hebrew Bible/Old Testament. The history of its beginnings, vol. 2, pp. 452-511, Vandenhoeck \& Ruprecht, Göttingen.

Human, D.J., 2004, 'Psalm 136: A liturgy with reference to creation and history', in D. Human \& C.J.A. Vos (eds.), Psalms and liturgy, pp. 73-88, T\&T Clark, London.

Human, D.J., 2005, 'Africa in need of an Exodus', in E. Otto \& J.H. le Roux (eds.), A critical study of the Pentateuch: An encounter between Europe and Africa, pp. 94-97, Lit, Munster.

Human, D.J., 2007, 'Psalm 93: Yahweh robed in majesty', in D.J. Human (ed.), Psalms and liturgy, pp. 147-169, T\&T Clark, London.

Human, J.J., 2006, 'n Lewe met boeke, Human \& Rousseau, Cape Town.

Kaiser, O., 2003, Der Gott des Alten Testment, Vandenhoeck \& Ruprecht, Göttingen

Kearney, R., 1989, Modern movements in European philosophy, University Press, Manchester.

Klopper, F., 2008, 'Quo vadis, feminist scholarship? Reflections from the threshold between African and European biblical exegesis', in H. de Wit \& G.O. West (eds.), African and European readers of the Bible in dialogue, pp. 183-193, Brill, Leiden.

Körtner, H.J., 2006, Einführung in die theologische Hermeneutik, Darmstadt, WBG

Kraus, H.-J., 1969, Geschichte der historisch-kritischen Erforschung des Alten Testaments, Neukirchener Verlag, Neukirchen.

Kritzinger, J.H., 1935, Die profesie van Joël, De Bussy, Amsterdam.

Kritzinger, J.H., 1939, Die skeppingsdae in Genesis, Van Schaik, Pretoria.

Kritzinger, J.H., 1963, 'Die stand van die Ou Testament aan ons fakulteit gedurende die afgelope kwarteeu', NGTT 4, 77-85.

Kritzinger, J.H., 1965, 'Outobiografie', Deo Gloria, 2-5.

Le Roux, J.H., 1992, 'Op die breuklyn', NGTT 33/3, 291-300.

Le Roux, J.H., 1993, A story of two ways, Verba Vitae, Pretoria.

Le Roux, J.H., 1994, 'A brief description of an intellectual journey: On Willem Vorster's quest for understanding', Neotestamentica 28/3, 1-32.

Le Roux, J.H., 1997, 'Our historical heritage', Old Testament Essays $10 / 3,401-423$

Le Roux, J.H., 2004, 'Augustine, Gadamer and the Psalms', in D.J. Human \& C.J.A. Vos (eds.), Psalms and liturgy, pp. 123-130, T\&T Clark, New York.

Le Roux, J.H., 2005, 'Pro Pent. A project for the study of the Pentateuch in South Africa', in E. Otto \& J.H. le Roux (eds.) A critical study of the Pentateuch: An encounter between Europe and Africa, pp. 1-21, Lit, Munster.

Le Roux, J.H., 2007, 'Setting the scene: The battle of the signs', in J.H. le Roux \& E. Otto (eds.), South African perspectives on the Pentateuch between synchrony and diachrony, pp. 1-18, T\&T Clark, New York.

Le Roux, J.H., 2008a, 'Africa and the future of our scholarly past', in H. de Wit \& G.O. West (eds.), African and European readers of the Bible in dialogue, pp. 307-323, Brill, Leiden.

Le Roux, J.H., 2008b, 'Confrontation with the African 'other': A response', in H. de Wit \& G.O. West (eds.), African and European readers of the Bible in dialogue, pp. 140-142, Brill, Leiden.

Loader, J.A., 1978, 'Gedagtes oor gekontroleerde eksegese', HTS Teologiese Studies/Theological Studies 34, 1-40.

Oftestad, T., 2008, 'Further developments of reformation hermeneutics', in M. Sæbø (ed.), Hebrew Bible/Old Testament. The history of its beginnings, vol. 2, pp. 602-616, Vandenhoeck \& Ruprecht, Göttingen. 
Opitz, P., 2008, 'The exegetical and hermeneutical work of John Oecolampaius, Huldrych Zwingli and John Calvin', in M. Sæbø (ed.), Hebrew Bible/Old Testament. The history of its beginnings, vol. 2, pp. 407-451, Vandenhoeck \& Ruprecht, Göttingen.

Otto, E., 1994, Theologische Ethik des Alten Testaments, Verlag W. Kohlhammer, Stuttgart.

Otto, E., 1995, 'Kritik der Pentateuchkomposition', ThR, 60, 163-191.

Otto, E., 1996, 'Neuere Einleitungen in den Pentateuchkritik', Theologische Rundschau, 61, 332-341.

Otto, E., 1997, 'Das Deuteronomium als archimedischer Punkt in der Pentateuchkritik', in M. Vervenne \& J. Lust (eds.), Deuteronomy and Deuteronomic literature, pp. 321-339, Peeters, Leuven.

Otto, E., 1998, 'Die Ursprünge der Bundestheologie im Alten Testament und im Alten Orient', ZAR 4, 1-84.

Otto, E., 1999a, Das Deuteronomium, Walter de Gruyter, Berlin.

Otto, E., 1999b, 'Deuteronomium', Religion in Geschichte und Gegenwart, 4(II), 693-696.

Otto, E., 1999c, 'Ethik III. Biblisch, I. AT', Religion in Geschichte und Gegenwart, 4(II), 1603-1606.

Otto, E., 2000a, Das Deuteronomium im Pentateuch und Hexateuch, J.C.B. Mohr, Tübingen.

Otto, E., 2000b, 'Mose und das Gesetz. Die Mose-figur als Gegenentwurf Politischer Theologie zur neuassyrischen Königsideologie im 7. Jh. v. Chr.', in E. Otto (ed.), Mose, pp. 43-83, Katholisches Bibelwerk GmbH, Stuttgart.

Otto, E., 2002, Gottes Recht als Menschenrecht. Rechts- und literaturhistorische Studien zum Deuteronomium, BZAR 2, Otto Harrossowitz, Wiesbaden.

Otto, E., 2005, 'The Pentateuch between synchrony and diachrony', in E. Otto \& J.H. le Roux (eds.), A critical study of the Pentateuch: An Encounter Between Europe and Africa, pp. 22-49, Lit, Munster.

Otto, E., 2007a, 'A hidden truth behind the text or the truth of the text: At a turning point in biblical scholarship two hundred years after De Wette's Dissertation Critico-Exegetica', in J.H. le Roux \& E. Otto (eds.), South African perspectives on the Pentateuch between synchrony and diachrony, pp. 19-28, T\&T Clark, New York.

Otto, E., 2007b, 'The pivotal meaning of Pentateuch research for a history of Israelite and Jewish religion and society', in J.H. le Roux \& E. Otto (eds.), South African perspectives on the Pentateuch between synchrony and diachrony, pp. 29-53, T\&T Clark, New York.

Otto, E., 2007c, 'Myth and Hebrew ethics in the Psalms', in D.J Human (ed.), Psalms and mythology, pp. 26-37, T\&T Clark, New York.

Pannenberg, W.H., 1970, Basic questions in theology, vol. 1, Hutchinson, London.

Popper, K., 1968, The logic of scientific discovery, Hutchinson, London.

Prinsloo, W.S., 1979, 'Die metodiek van eksegese: 'n diskussie', Nederduits Gereformeerde Teologiese Tydskrif 20(3), 201-210.

Prinsloo, W.S., 1980, 'The theology of the book of Ruth', Zeitschrift für die alttestamentliche Wissenschaft 30, 331.

Prinsloo, W.S., 1981, 'Isaiah 14:12-15: Humiliation, hubris, humiliation', Zeitschrift für die alttestamentliche Wissenschaft 93, 432-433.

Prinsloo, W.S., 1983, 'Die boek Joël: Verleentheid of geleentheid?', Nederduits Gereformeerde Teologiese Tydskrif 24(3), 255-256.

Prinsloo, W.S., 1984, Van kateder tot kansel, N.G. Kerkboekhandel, Pretoria.

Prinsloo, W.S., 1985, The theology of the book of Joel, De Gruyter, Berlin.

Prinsloo, W.S., 1987, Die Ou Testament, 'n verouderde boek? Enkele gedagtes na aanleiding van Psalm 15, University of Pretoria, Pretoria.

Prinsloo, W.S., 1988, 'Die histories-kritiese metode(s) in perspektief', Skrifen Kerk 9(2), 196-209.
Prinsloo, W.S., 1991, Die psalms leef, N.G. Kerkboekhandel, Pretoria.

Prinsloo, W.S., 1992, 'The unity of the book of Joel', Zeitschrift für die alttestamentliche Wissenschaft 104(1), 66-81.

Prinsloo, W.S., 2000, 'Psalm 93: Jahwe is van altyd af koning oor alles en almal', in D.J. Human (ed.), Die lof van my God solank ek lewe: Verklaring van aantal psalms deur WS Prinsloo, pp. 141-154, Medpharm Publikasies, Pretoria.

Reventlow, H.G., 1997, Epochen der Bibelauslegung. Renaissance, Reformation, Humanismus, vol. 3, C.H. Beck, München.

Rossouw, H., 1993, Universiteit, wetenskap en kultuur, Tafelberg, Cape Town.

Snoek, H., 2008, 'Key concepts in the dialogue between African and European biblical scholars', in H. de Wit \& G.O. West (eds.), African and European readers of the Bible in dialogue, pp. 85-106, Brill, Leiden.

Steyn, J.C., 2008, Sonkyker. Afrikaner in die verkeerde eeu, Tafelberg, Cape Town.

Terblanche, H.O., 1998, Nederland en die Afrikaner: Gesprek oor apartheid, University of Port Elizabeth, Port Elizabeth.

Thiselton, A.C., 1980, The two horizons, Pater Noster, Exeter.

Van Huyssteen, W., 1986, Teologie as kritiese geloofsverantwoording, RGN, Pretoria.

Van Niekerk, A., 1993a, 'Ter inleiding', in H. Rossouw (ed.), Universiteit, wetenskap en kultuur, pp. 1-10, Tafelberg, Cape Town.

Van Niekerk, A., 1993b, 'Voorwoord', in A. van Niekerk \& W. Esterhuyse (eds.), Intellektueel in konteks, pp. i-iv, RGN, Pretoria.

Van Niekerk, A., 1993c, 'Wetenskap, kultuur en universiteit in die denke van Hennie Rossouw', in A. van Niekerk \& W. Esterhuyse (eds.), Intellektueel in konteks, pp. 1-43, RGN, Pretoria.

Van Zyl, A.H., 1960, The Moabites, Brill, Leiden.

Van Zyl, A.H., 1967, Moses by die brandende braambos, Universiteit van Pretoria, Pretoria.

Van Zyl, A.H., 1970, 'Die akademiese vorming van die bedienaar van die Woord', Nederduits Gereformeerde Teologiese Tydskrif 11, 180-189.

Van Zyl, A.H., 1972a, 'Die mens: Selfstandige werker of medewerker van God?' Nederduits Gereformeerde Teologiese Tydskrif 13, 65-76.

Van Zyl, A.H., 1972b, 'Literêre vorme en eksegese', Nederduits Gereformeerde Teologiese Tydskrif 13, 149-159.

Van Zyl, A.H., 1973, 'Redaksiegeskiedenis en prediking', Nederduits Gereformeerde Teologiese Tydskrif 14, 114-125.

Van Zyl, A.H., 1975, 'Gods Woord in mensetaal', vol. 1, Butterworths, Durban.

Van Zyl, A.H., 1983, Die gesag van die Ou Testament, N.G. Kerkboekhandel, Pretoria.

Van Zyl, A.H., 1987, Hy wat sou kom. Messiaanse prediking in die Ou Testament, N.G. Kerk-boekhandel, Pretoria.

Von Rad, G., 1971, 'Das Formgeschichtliche Problem des Hexateuch', in Gesammelte Studien zum Alten Testament, pp. 9-86, Chr Kaiser, München.

Von Rad, G., 1973, 'Offene Fragen im Umkreis einer Theologie des AltenTestament', in Gesammelte Studien zum Alten Testament, pp. 289-312, Chr Kaiser, München.

Vorster, W.S., 1971, 'Moderne linguïstiek en Bybelnavorsing', Africa Journal of Evangelical Theology 4, 139-148.

Welker, M., 2008, 'Sola Scriptura. Die Autorität der Bibel in pluralistischen Umgebungen', in B. Hamm \& M. Welker (Hrsg.), Die Reformation. Potentiale der Freiheit, pp. 91-120, Mohr Siebeck, Tübingen.

West, G., 2008, 'Interrogating the comparative paradigm in African biblical scholarship', in H. de Wit \& G.O. West (eds.), African and European readers of the Bible in dialogue, pp. 37-64, Brill, Leiden.

Zenger, E., 2008, 'Die Bücher der Tora/des Pentateuch', in E. Zenger (Hrsg), Einleitung in das Alte Testament, pp. 60-187, Kohlhammer, Stuttgart. 